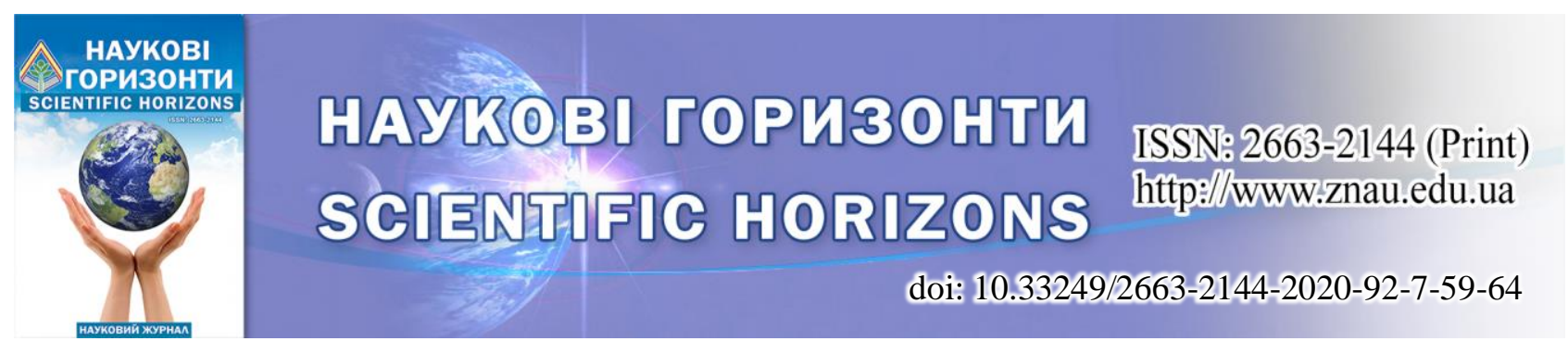

UDC 619:616.99:595.421

\title{
RODENTS AS A PERSISTENT SOURCE OF TICK-BORNE DISEASES
}

Article info

Received

11.05.2020

Accepted

24.06.2020

${ }^{1}$ State Agrarian and Engineering University in Podilya

13, Shevchenko Str., KamianetsPodilskyi, 32300, Ukraine

${ }^{2}$ Sumy National Agrarian University 160, Gerasim Kondratiev, Sumy, 40000, Ukraine

E-mail: Levytska28@ gmail.com

\section{Levytska ${ }^{1}$, A. Mushynskyi ${ }^{1}$, A. Berezovskyi ${ }^{2}$}

Levytska, V., Mushynskyi, A., Berezovskyi, A. (2020). Rodents as a persistent source of tick-borne diseases. Scientific Horizons, 07 (92), 59-64. doi: 10.33249/2663-2144-2020-92-7-59-64.

Diseases transmitted by ticks usually have a very complex environment and their prevalence, frequency, seasonality and long-term dynamics are influenced by various factors. The aim of our study was to study the role of rodents in the life cycle of I. ricinus. The research was conducted in the forests of Khmelnytsky, Chernivtsi and Vinnytsia regions. In the forests of the three regions, nine plots measuring $100 \times 100 \mathrm{~m}$ were selected. Traps were set for catching rodents in each plot. Caught rodents were examined for the presence of all stages of ticks. It was found that european mouse (Sylvaemus sylvaticus), yellow-breasted mouse (Sylvimus flavicollis) and field mouse (Apodemus agrarius) were found in all three regions.

A total of 159 rodents were caught in the experiment. Of these, 34 european mice, 49 yellow-breasted mice, 76 field mice, all were examined for ticks. The most affected was the european mouse, which lives not only in forests, but also in parks and gardens, floodplains and gardens. Ticks larvae were detected in $88.2 \%$ of individuals. The average number of larvae detected in the european mouse was 16, which was significantly higher than the average number of larvae in the yellow-breasted mouse, which was 8. The yellow-breasted mouse was also infested with larvae in $73.5 \%$. The field mouse was the least affected, at $61.8 \%$, and the average number of larvae per individual was 4. Larvae and nymphs were mainly attached to the rodent's head, also to the body, and much less to the limbs. In populations of all rodents, a slight lesion predominated in most individuals. A maximum of 29 ticks were found in the european mouse, 18 in the yellow-breasted mouse, and 6 in the field mouse. It was found in the age dynamics that all young rodents were less infested than the older ones. It was also found that the intensity of males is 1.5 times higher than females for all species of rodents. The intensity of the invasion is highest in the summer months (July-August) and decreased slightly in autumn. Studies conducted in three areas allow us to characterize the role of three species of rodents as feeders of the preimaginal stages of development of Ixodid ticks and to note some features of the disease of each species.

Key words: Ixodid ticks, Ixodes ricinus, rodents, tick-borne diseases.

\section{МИШОПОДІБНІ ГРИЗУНИ ЯК ПЕРСИСТЕНТНЕ ДЖЕРЕЛО ТРАНСМІСИВНИХ ХВОРОБ}

В. А. Левицька ${ }^{1}$, А. Б. Мушинський ${ }^{1}$ А. В. Березовський ${ }^{2}$

${ }^{1}$ Подільський державний аграрно-технічний університет вул. Шевченка, 13, м. Кам'янець-Подільський, 32300, Україна

${ }^{2}$ Сумський національний аграрний університет

вул. Герасима Кондратьєва, 160, м. Суми, 40000, Україна

Захворювання, щчо переносяться кліщами, зазвичай мають дуже складну екологію $i$ на їх поширення, частоту, сезонність та багаторічну динаміку впливають різні чинники. На щільність 
V. Levytska, A. Mushynskyi, A. Berezovskyi поширеності кліщуів I. ricinus впливають різні фактори, серед яких найважливіме місце займає чисельність сприйнятливих господарів. Метою нашого дослідження було вивчення ролі гризунів в ииклі розвитку I. ricinus. Дослідження проводили у лісових господарствах Хмельницької, Чернівецької та Вінницької областей. В лісах трьох областей було відібрано дев'ять ділянок розміром $100 \times 100$ м. На кожній ділянщі було встановлено пастки для відлову гризунів. Виловлених гризунів досліджували на наявність всіх стадій кліщів I. ricinus.

Встановлено, щьо у всіх трьох областях у лісових господарствах було виявлено мишака європейського (Sylvaemus sylvaticus), мишака жовтогрудого (Sylvimus flavicollis) та мишу польову (Apodemus agrarius).

Всього в експерименті було спіймано 159 гризунів. 3 них мишака європейського - 34, мишака жовтогрудого - 49, миші польової- 76, всіх обстежено на наявність кліщів. Найбільше був уражений мишак європейський, який мешкає не лише у лісі, але і в садах та на городах, а також у парках. Личинки кліщуів були виявлені у 88,2 \% особин. Середня кількість личинок, виявлених на мишаку європейському, становила 16, що було значно вище, ніж середня кількість личинок на мишаку жовтогрудому, що становило 8. Мишак жовтогрудий також був інвазований кліщами у 73,5 \%. Миша польова найменше була уражена, що становило 61,8\%, середня кількість кліщів на одній особині становила 4. Личинки та німфи в основному були прикріплені в області голови гризунів, також на тілі $і$ значно менше на кіниівках. У популяціях всіх мишей переважало незначне ураження у більшості особин. Максимально у мимака європейського було виявлено 29 кліщів, у мишака жовтогрудого - 18, миші польової- 6. У віковій динаміці встановлено, щзо всі молоді особини гризунів інвазовані менше, ніж старші. Також встановлено, що інтенсивність ураження самиів у 1,5 раза вище, ніж самок для всіх видів гризунів. Інтенсивність інвазії найвища у літні місяці (липень-серпень) і дещо знижувалася восени. Дослідження, проведені в трьох областях, дозволяють охарактеризувати роль трьох масових видів гризунів як живителів преімагінальних стадій розвитку іксодових кліщів $i$ відзначити деякі особливості ураженості кожного виду.

Ключові слова: іксодові кліщі, Iходеs ricinus, гризуни, трансмісивні хвороби.

\section{Вступ}

Гризуни - одні з найважливіших господарів, які підтримують цикл розвитку певних видів іксодових кліщів у Центральній та Східній Свропі та вирішальний фактор у формуванні динаміки популяції $I$. ricinus. Просторова та часова синхронія гризунів помірних регіонів 3 паразитуванням преімагінальних стадій розвитку I. ricinus створюють оптимальні умови не тільки для розвитку великої кількості кліщів, але і для передачі збудників важливих захворювань. Це робить деякі види гризунів ключовими гравцями щорічного циклу таких важливих захворювань, як бореліоз та вірусний енцефаліт.

Захворювання, що переносяться кліщами, зазвичай мають дуже складну екологію і на їх поширення, частоту, сезонність та багаторічну динаміку впливають різні чинники. Порівняно 3 іншими членистоногими гематофагами, іксодові кліщі мають особливу біологію, оскільки живляться лише одним шляхом. Оскільки більшість іксодових кліщів протягом життєвого циклу використовують трьох господарів, це означає, що під час певної стадії розвитку кожен окремий кліщ буде живитись на трьох окремих господарях. Отже, контакт між потенційним переносником-кліщем та сприйнятливим господарем (резервуарним) обмежений максимум трьома на покоління. Як наслідок, кожен набутий збудник передається наступному господареві на наступній стадії розвитку кліща. Отже, необхідною умовою для передачі збудників у іксодових кліщів $є$ трансстадіальне забезпечення передачі або трансоваріальна передача збудника (Randolph et al., 2004).

3 медичної та ветеринарної точок зору, збудники трансмісивних хвороб особливо важливі, оскільки вони викликають захворювання у людей. Однак не всі відомі збудники хвороб, що переносяться кліщами, $\epsilon$ небезпечними для людини. Це не означає, що вони не становлять загрози для людини, однак певні екологічні фактори обмежують можливість передачі їх людині. В деяких країнах світу кількість кліщів, зафіксованих на людині, може бути дуже високою, однак, таких видів кліщів існує досить мало (Estrada-Peña \& Jongejan, 1999; DantasTorres et al., 2012). У Центральній та Східній Європі Ixodes ricinus є домінуючим видом кліщів, який уражує людей, тварин, птахів та гризунів у 
V. Levytska, A. Mushynskyi, A. Berezovskyi

лісовому середовищі і має понад 300 видів господарів (Roczeń-Karczmarz et al., 2018; Левицька та Мушинський, 2020). Однак значення цих господарів у поширенні кліщових захворювань неоднакове і залежить від певних факторів: чисельності господарів під час піків активності кліщів; доступності господаря для живлення кліщів; можливості окремого господаря одночасно бути живителем для різних стадій розвитку (личинки, німфи); здатності господарів підтримувати та передавати збудників кліщам; здатності господаря одночасно передавати кілька патогенів кліщам.

На щільність поширеності кліщів I. ricinus впливають різні фактори, серед яких найважливіше місце займає чисельність сприйнятливих господарів (Randolph, 2004). Крім того, рівень зараження певними збудниками кліщів залежить від резервуарних господарів. Гризуни $\epsilon$ гарною епідеміологічною моделлю для вивчення екології хвороб. Через їх численність, доведено їх роль як резервуарних господарів важливих патогенів людини і тварин та як господарів для кліщів. Отже, метою нашого дослідження було вивчення ролі гризунів в циклі розвитку I. ricinus. Екологія популяції та розповсюдження деяких видів гризунів тісно пов'язані з епізоотологічною ситуацією серед тварин та епідеміологічною ситуацією серед людей.

\section{Матеріали та методи}

Дослідження проводили протягом 20182019 рр. у лісових господарствах Хмельницької, Чернівецької та Вінницької областей. В усіх лісах переважали листяно-хвойні породи дерев, а також зареєстровано різноманітні види ссавців та птахів. Облік та дослідження гризунів проводили за двома напрямками - облік видового складу та чисельності, водночас враховували вік та стать. Для порівняння даних про рясноту виду і для збору масового матеріалу, використовували загальноприйняті підходи до обліку гризунів. Варто відзначити, що в дослідженні використовували живоловки, що дозволяли зберегти тварин живими. У подальшому, після ідентифікації та опрацювання (огляду, підрахунку, визначення статі та віку) тварини були відпущені на волю. Зібраний при обліках матеріал був опрацьований за ключами (Zahorodniuk, 2002).

В лісових господарствах трьох областей було відібрано дев'ять ділянок розміром $100 \times 100$ м.
Пастки 3 приманкою виставляли у лінію по 20 штук. Таку лінію закладали в межах однорідної місцевості, витримуючи між суміжними пастками відстань 5 м. Пастки експонували 2 доби у період вечірньої та ранкової активності гризунів, а саме від раннього вечора до наступного півдня. Обстеження пасток на наявність гризунів проводили після сходу сонця - один раз на добу. Для збільшення щільності гризунів на всіх ділянках розташовували принади. Виловлених гризунів досліджували на наявність всіх стадій кліщів I. ricinus. Період зборів - з вересня 2018 по вересень 2019 року для дослідження залежності між температурою та початком активності кліщів і гризунів.

\section{Результати досліджень та обговорення}

Встановлено, що у всіх трьох областях у лісових господарствах було виявлено мишака європейського (Sylvaemus sylvaticus), мишака жовтогрудого (Sylvimus flavicollis) та мишу польову (Apodemus agrarius).

Всього в експерименті було спіймано 159 гризунів. 3 них мишака європейського - 34, мишака жовтогрудого - 49, миші польової - 76, всіх обстежено на наявність кліщів. Найбільше був уражений мишак європейський, який мешкає не лише у лісі, але і в садах та на городах, а також у парках. Личинки і німфи кліщів I. ricinus були виявлені на 30 гризунах, що становить $88,2 \%$ (табл. 1). Середня кількість личинок і німф, виявлених на мишаку європейському, становила 16 , що було значно вище, ніж середня кількість личинок на мишаку жовтогрудому, що становило 8. Мишак жовтогрудий також був інвазований кліщами у 73,5\%, що становило 36 особин. Миша польова найменше була уражена - 47 особин, що становило $61,8 \%$, середня кількість кліщів на одній особині - 4. Личинки та німфи в основному були прикріплені в області голови гризунів, також на тілі і значно менше на кінцівках. У популяціях всіх мишей переважало незначне ураження у більшості особин. Максимально у мишака європейського було виявлено 29 кліщів, у мишака жовтогрудого - 18, миші польової - 6. У віковій динаміці встановлено, що всі молоді особини гризунів інвазовані менше, ніж старші. Також встановлено, що інтенсивність ураження самців у 1,5 раза вище, ніж самок для всіх видів гризунів. Інтенсивність інвазії найвища у літні місяці (липень-серпень) і дещо знижувалася восени. 
V. Levytska, A. Mushynskyi, A. Berezovskyi

Таблиця 1. Мишоподібні гризуни Хмельницької, Чернівецької та Вінницької областей та ступінь їх ураження незрілими формами іксодових кліщів

\begin{tabular}{|l|c|c|c|}
\hline \multicolumn{1}{|c|}{ Вид гризунів } & $\begin{array}{c}\text { Виловлено } \\
\text { гризунів, особин }\end{array}$ & $\begin{array}{c}\text { Уражено личинками } \\
\text { і німфами кліщів } \\
\text { I. } \text { ricinus } \\
\text { (самок/самців) }\end{array}$ & $\begin{array}{c}\text { Екстенсивність } \\
\text { інвазії ( \%) }\end{array}$ \\
\hline Sylvaemus sylvaticus & 34 & $30(12 / 18)$ & 88,2 \\
\hline Sylvimus flavicollis & 49 & $36(14 / 22)$ & 73,5 \\
\hline Apodemus agrarius & 76 & $47(19 / 28)$ & 61,8 \\
\hline Всього & 159 & $113(45 / 68)$ & 71,1 \\
\hline
\end{tabular}

Дослідження, проведені в трьох областях, дозволяють охарактеризувати роль трьох масових видів гризунів як живителів преімагінальних стадій розвитку іксодових кліщів і відзначити деякі особливості ураженості кожного виду. Гризуни в помірних географічних регіонах демонструють циклічне коливання популяції, яке зазвичай має щорічні цикли (на відміну від багаторічних циклів гризунів у помірнопрохолодних регіонах), водночас більшість видів у центральноєвропейському регіоні досягають максимуму популяції наприкінці літа або на початку осені $(K r e b s, 2013)$. Цей пік корелює 3 піком щільності преімагінальних стадій кліщів $I$. ricinus і спостерігається в нашому дослідженні, а також в багатьох регіонах Європи. Більше того, це період високої активності більшості видів гризунів, тому вони переносять значну кількість проміжних стадій розвитку кліщів. Найменша кількість популяції гризунів спостерігається ранньою весною, що ми також спостерігали. В цей період, серед кліщів найбільша чисельність дорослих стадій, які не потребують проміжних господарів гризунів, але, як правило, паразитують на більших ссавцях (види, що не мають таких щорічних коливань популяціï). Таким чином, відбувається синхронізація розвитку кліщів I. ricinus та густоти популяції гризунів, завдяки чому вони $є$ оптимальними господарями для цього виду кліща (Randolph et al., 2002).

За різними даними встановлено, що чим більший господар, тим більший рівень ураженості паразитами. Цю кореляцію між залежністю від розміру та інтенсивністю паразитизму можна виявити як між господарями різних видів, так і між особинами одного і того ж виду. Причинні фактори - фізичні, поведінкові або імунологічні, які діють індивідуально або синергічно. Більш великі господарі (наприклад, олені, лисиці), які зазвичай переносять багато кліщів, як правило, знаходяться в значно меншій щільності, ніж гризуни. 3 іншого боку, навіть якщо інтенсивність паразитизму кліщів у дрібних гризунів значно менша, їх чисельність це компенсує (Randolph, 2004). Отже, загалом невеликі та численні групи гризунів можуть забезпечити умови паразитування певним локальним популяціям кліщів, що було нами підтверджено.

Встановлено, що різні види гризунів можуть бути господарями для I. ricinus у Центральній та Східній Європі. Основний перелік господарів включає: Muscardinus avellanarius, Mus musculus, Glis glis, Myodes glareolus, Arvicola amphibius, Apodemus flavicollis, A. agrarius, A. sylvaticus, A.flavicollis, A. uralensis, Cricetus cricetus, Dryomys nitedula, Chionomys nivalis, Eliomys quercinus, Micromys minutus, M. arvalis, M. tatricus, M. subterraneus, $M$. agrestis, Sciurus vulgaris, Rattus norvegicus (Matuschka et al., 1991; Mihalca \& Sandor, 2013; Pérez et al., 2012).

Однак за деякими дослідженнями встановлено, що певні види гризунів частіше $\epsilon$ господарями для кліщів I. ricinus. У Німеччині серед найважливіших господарів личинок і німф $€$ A. flavicollis, A. agrarius та $M$. glareolus (Matuschka, 1991). У Франції та Румунії основним господарем незрілих стадій був M. arvalis (L'Hostis et al., 1996; Mihalca et al., 2012). Встановлено, що A. uralensis та A. sylvaticus $\epsilon$ важливими господарями для личинок та німф I. ricinus у Румунії. 3 іншого боку, хоча популяції деяких видів гризунів зазвичай в цілому або локально рясні (M. musculus, M. spicilegus, $R$. norvegicus), вони рідко переносять $I$. ricinus, $\mathrm{i}$ якщо їх і виявлять, то інтенсивність ураження зазвичай низька (Paulauskas et al., 2009; Mihalca et $a l ., 2012)$. Ця закономірність може бути пов'язана 3 відмінностями в ареалах та активністю цих видів, оскільки деякі види Mus живуть 
V. Levytska, A. Mushynskyi, A. Berezovskyi

невеликими популяціями на відміну від більшості видів Apodemus, крім того у більшості Microtus піки щоденної активності співпадають 3 найбільш активними періодами збору кліщів (Randolph et al., 2002; Krebs, 2013).

Незважаючи на те, що ця кореляція піків активності кліщів із синхронною чисельністю популяцій гризунів є загальною тенденцією, спостерігаються видові специфічні відмінності, які можуть бути спричинені відмінностями в екології господарів. Виявлено, що певні господарі (тобто A. agrarius), як правило, сильніше уражені німфами I. ricinus, ніж інші (наприклад, $M$. glareolus або A. flavicollis) через синхронну кількість господарів-кліщів. Крім того, існує припущення, що влітку, коли питома чисельність гризунів локально низька, а кліщі ще активні, вони живляться на ящірках, які можуть впливати негативно на цикл передачі B. burgdorferi s.l.

Ще одним важливим фактором передачі збудників трансмісивних хвороб $є$ співвідношення пікових активностей личинок i німф. Гризуни відіграють особливу роль, оскільки деякі види можуть бути живителями для обох стадій синхронно, що ми також спостерігали у нашому дослідженні i це підтверджено експерментально (Matuschka et al., 1991; Mihalca et al., 2012). Це має вирішальне значення для існування природного резервуара збудників, до прикладу вірусний кліщовий енцефаліт, збудник якого зберігається в організмі гризунів лише короткий час. Це явище рідко зустрічається серед м'ясоїдних або серед великих травоїдних тварин (Széll et al., 2006; Ruiz-Fons \& Gilbert, 2010).

Після живлення кожна стадія розвитку кліща відкріплюється від господаря. Тим не менше, тривалість живлення та період існування відкріплених кліщів залежить від різних факторів, причому вид господаря $\epsilon$ одним iз найважливіших. Після укусу личинки спостерігається набута стійкість до кліщів I. ricinus, це було описано у виду M. glareolus. Це явище призводить до зменшення ваги та зниження виживання у німф. Це ж дослідження показало, що імунітет після укусу до кліщів I. ricinus відсутній у A. flavicollis (Dizij \& Kurtenbach, 1995). Так само було встановлено, що A. sylvaticus виробляє значно нижчий набутий імунітет до I. trianguliceps, ніж лабораторні миші. Імунітет гризунів до кліщів також залежить від рівня статевих гормонів. У гризунів $M$. glareolus та A. sylvaticus 3 високим рівнем тестостерону виявляли знижену вроджену та набуту стійкість до укусів I. ricinus (Hughes \& Randolph, 2001). Однак іншим дослідженням не було виявлено різниці між статевою перевагою кліщів у двох видів гризунів A. sylvaticus та $M$. glareolusus (Kiffner et al., 2011). Більше того, кілька експериментальних досліджень показали, що деякі види гризунів уражуються кліщами більше, ніж інші. Дослідженнями встановлено, що у випадку B. burgdorferi s.l., вид M. glareolus виявився більш інвазованим кліщами, ніж $A$. sylvaticus (Pérez et al., 2012). Коли ураженість кліщами I. ricinus оцінювали за B. afzelii, вид гризунів $M$. glareolus також був більш ураженим, ніж A. sylvaticus та A. flaviocollis. Коли два види гризунів 3 роду Apodemus (A. flavicollis та $A$. sylvaticus) порівнювали за їх зараженістю $B$. burgdorferi s.l. до I. ricinus, суттєвих відмінностей не було виявлено (Gern et al., 1994).

\section{Висновки}

1. У Хмельницькій, Чернівецькій та Вінницькій областях у лісових господарствах було виявлено мишака європейського (Sylvaemus sylvaticus) - 34 особини, мишака жовтогрудого (Sylvimus flavicollis) - 49 та мишу польову (Apodemus agrarius) - 76. Всього в експерименті було спіймано 159 гризунів.

2. Найбільше був уражений мишак європейський - личинки і німфи кліщів I. ricinus були виявлені на 30 гризунах, що становить $88,2 \%$. Мишак жовтогрудий також був інвазований кліщами у 73,5\%, що становило 36 особин. Миша польова найменше була уражена - 47 особин, що становило 61,8\%.

3. Максимально у мишака європейського було виявлено 29 кліщів, у мишака жовтогрудого 18, миші польової - 6. У віковій динаміці встановлено, що всі молоді особини гризунів інвазовані менше, ніж старші. Також встановлено, що інтенсивність ураження самців у 1,5 раза вище, ніж самок для всіх видів гризунів. Інтенсивність інвазії найвища у літні місяці (липень-серпень) і дещо знижувалася восени.

\section{References}

Dantas-Torres, F., Chomel, B. B. \& Otranto, D. (2012). Ticks and tick-borne diseases: a one health perspective. Trends Parasitol. 28, 437-446. doi: 10.1016/j.pt.2012.07.003.

Dizij, A. \& Kurtenbach, K. (1995). Clethrionomys glareolus, but not Apodemus 
V. Levytska, A. Mushynskyi, A. Berezovskyi

flavicollis, acquires resistance to Ixodes ricinus L., the main European vector of Borrelia burgdorferi. Parasite Immunology, 17, 177-183. doi: 10.1111/j.1365- 3024.1995.tb00887.x.

Estrada-Peña, A. \& Jongejan, F. (1999). Ticks feeding on humans: a review of records on humanbiting Ixodoidea with special reference to pathogen transmission. Exp. Appl. Acarol., 23, 685-715. doi: 10.1023/A:1006241108739.

Gern, L., Siegenthaler, M., Hu, C. M., LeubaGarcia, S., Humair, P. F. \& Moret, J. (1994). Borrelia burgdorferi in rodents (Apodemus flavicollis and A. sylvaticus): duration and enhancement of infectivity for Ixodes ricinus ticks. Eur. J. Epidemiol., 10, 7580. doi: 10.1007/BF01717456.

Hughes, V. L. \& Randolph, S. E. (2001). Testosterone depresses innate and acquired resistance to ticks in natural rodent hosts: a force for aggregated distributions of parasites. J. Parasitol., 87, 49-54. doi: 10.1645/0022-3395(2001)087[0049: TDIAAR]2.0.CO;2.

Kiffner, C., Vor, T., Hagedorn, P., Niedrig, M. \& Rühe, F. (2011). Factors affecting patterns of tick parasitism on forest rodents in tick-borne encephalitis risk areas, Germany. Parasitol. Res., 108, 323-335. doi: 10.1007/s00436-010- 2065-x.

Krebs, C. J. (2013). Population Fluctuations in Rodents. Chicago; London : University of Chicago Press. doi: 10.7208/chicago/ 9780226010496.001.0001.

L'Hostis, M., Dumon, H., Fusade, A., Lazareff, S. \& Gorenflot, A. (1996). Seasonal incidence of Ixodes ricinus ticks (Acari: Ixodidae) on rodents in western France. Exp. Appl. Acarol., 20, 359-368. doi: 10.1007/BF00130548.

Levytska, V. A., Mushynskyi, A. B. \& Berezovskyi, A. V. (2020). Vydovyi sklad iksodovykh klishchiv u Zakhidnomu rehioni Ukrainy [Species composition of Ixodes mites in the Western region of Ukraine]. Naukovyi visnyk Lvivskoho natsionalnoho universytetu veterynarnoi medytsyny ta biotekhnolohii imeni S. Z. Gzhytskoho, 22 (97), 187-193. doi: https://doi.org/10.32718/nvlvet9730 [in Ukrainian].

Matuschka, F. R., Fischer, P., Musgrave, K., Richter, D. \& Spielman, A. (1991). Hosts on which nymphal Ixodes ricinus most abundantly feed. Am. J. Trop. Med. Hyg., 44, 100-107.

Mihalca, A. D. \& Sandor, A. D. (2013). The role of rodents in the ecology of Ixodes ricinus and associated pathogens in Central and Eastern Europe. Front. Cell. Infect. Microbiol, 3, 1-3.

Mihalca, A. D., Gherman, C. M., Magdas, C., Dumitrache, M. O., Györke, A., Sándor, A. D. ... Cozma, V. (2012). Ixodes ricinus is the dominant questing tick in forest habitats from Romania: the results from a countrywide dragging campaign. Exp. Appl. Acarol., 58, 175-182. doi: 10.1007/s10493012-9568-3.

Paulauskas, A., Radzijevskaja, J., Rosef, O., Turcinaviciene, J. \& Ambrasiene, D. (2009). Infestation of mice and voles with Ixodes ricinus ticks in Lithuania and Norway. Est. J. Ecol., 58, 112-125. doi: 10.3176/eco.2009.2.05.

Pérez, D., Kneubühler, Y., Rais, O. \& Gern, L. (2012). Seasonality of Ixodes ricinus ticks on vegetation and on rodents and Borrelia burgdorferi sensu lato genospecies diversity in two Lyme borreliosisendemic areas in Switzerland. Vector Borne Zoonotic Dis., 12, 633-644. doi: 10.1089/vbz.2011.0763.

Randolph, S. E. (2004). Tick ecology: processes and patterns behind the epidemiological risk posed by ixodid ticks as vectors. Parasitology, 129, 37-65. doi: 10.1017/S0031182004004925.

Randolph, S. E., Green, R. M., Hoodless, A. N. \& Peacey, M. F. (2002). An empirical quantitative framework for the seasonal population dynamics of the tick Ixodes ricinus. Int. J. Parasitol., 32, 979-989. doi: 10.1016/S0020-7519(02)00030-9.

Roczeń-Karczmarz, M., Dudko, P., DemkowskaKutrzepa, M., Meisner, M., Studzińska, M., Junkuszew, A. ... Tomczuk, K. (2018). Comparison of the occurrence of tick-borne diseases in ticks collected from vegetation and animals in the same area. Medycyna Weterynaryjna, 74, 484-488.

Ruiz-Fons, F. \& Gilbert, L. (2010). The role of deer as vehicles to move ticks, Ixodes ricinus, between contrasting habitats. Int. J. Parasitol., 40, 1013-1020. doi: 10.1016/j.ijpara.2010.02.006.

Széll, Z., Sréter-Lancz, Z., Márialigeti, K. \& Sréter, T. (2006). Temporal distribution of Ixodes ricinus, Dermacentor reticulatus and Haemaphysalis concinna in Hungary. Vet. Parasitol., 141, 377-379. doi: 10.1016/j.vetpar.2006. 06.008.

Zahorodniuk, I. V. (2002). Polovyy̆ vyznachnyk dribnykh ssavtsiv Ukrayiny [Field determinant of small mammals of Ukraine]. Kyiv [in Ukrainian]. 